The Canadian Mineralogist

Vol. 44, pp. 1147-1158 (2006)

\title{
THE CRYSTAL STRUCTURE OF $(\mathrm{Be}, \square)\left(\mathrm{V}, \mathrm{Ti}_{3} \mathrm{O}_{6}\right.$, A MINERAL RELATED TO KYZYLKUMITE
}

\author{
GUNNAR RAADE ${ }^{\S}$ \\ Department of Geology, Natural History Museum, University of Oslo, P.O. Box 1172 Blindern, NO-0318 Oslo, Norway \\ TONČI BALIĆ-ŽUNIĆ \\ Geological Institute, University of Copenhagen, Øster Voldgade 10, DK-1350 Kobenhavn K, Denmark
}

\begin{abstract}
The crystal structure of $(\mathrm{Be}, \square)(\mathrm{V}, \mathrm{Ti})_{3} \mathrm{O}_{6}$, a mineral discovered in the emerald deposit of Byrud, Norway, has been solved and refined to $R_{1}=4.51 \%$ for 1413 unique reflections. The structure is orthorhombic, Pnma, with lattice parameters $a 9.982(1)$, $b$ 8.502(1), $c$ 4.5480(6) $\AA, Z=4$, and isotypic with norbergite, $\mathrm{Mg}_{3} \mathrm{SiO}_{4} \mathrm{~F}_{2}$. The empirical chemical formula, based on the electron-microprobe determination of elements heavier than oxygen, and beryllium tentatively calculated to give $1 \mathrm{Be}$ for $\mathrm{O}=6$, is $\mathrm{Be}\left(\mathrm{V}^{3+}{ }_{1.27} \mathrm{Ti}_{1.21} \mathrm{Cr}_{0.29} \mathrm{Fe}_{0.08} \mathrm{Al}_{0.07}\right)_{\Sigma 2.92} \mathrm{O}_{6}$. The presence of Be was verified by the structure analysis and a SIMS analysis. The occupancy of the Be site was found to be 0.84(1), which largely explains the surplus of Ti in the empirical formula, as compared to the stoichiometric formula $\mathrm{BeV}_{2} \mathrm{TiO}_{6}$. However, there is no evidence for ordering of $\mathrm{V}$ and $\mathrm{Ti}$ on two unique octahedral sites of the structure. The amended empirical formula is $\left(\mathrm{Be}_{0.84} \square_{0.16}\right)\left(\mathrm{V}^{3+}{ }_{1.32} \mathrm{Ti}_{1.25} \mathrm{Cr}_{0.29} \mathrm{Fe}_{0.09} \mathrm{Al}_{0.07}\right)_{\Sigma 2.02} \mathrm{O}_{6}$. The appearance of the mineral, the dominance of $\mathrm{V}$ and $\mathrm{Ti}$ in its composition, and the $\mathrm{X}$-ray powder-diffraction data correspond to those described originally for kyzylkumite, supposed to be $\mathrm{V}_{2} \mathrm{Ti}_{3} \mathrm{O}_{9}$. The crystal-lattice parameters found earlier for kyzylkumite can be explained as based on an $8 \times$ supercell obtained on a $\{210\}$ reflection twin. This type of twinning is characteristic for the Byrud mineral, and is present in the crystal used for the structure determination. These facts suggest that the same type of oxide of $\mathrm{Be}, \mathrm{V}$ and Ti found at Byrud is also the main constituent of material described as kyzylkumite, which probably also contains additional phases, and that a redefinition of this mineral is needed.
\end{abstract}

Keywords: kyzylkumite, $(\mathrm{Be}, \square)(\mathrm{V}, \mathrm{Ti})_{3} \mathrm{O}_{6}$, norbergite isotype, leucophoenicite-humite series, crystal structure, twin, $\mathrm{V}-\mathrm{Ti}-\mathrm{Be}$ oxide, Byrud emerald deposit, Norway.

\section{SOMMAIRE}

Nous avons résolu et affiné la structure cristalline de $(\mathrm{Be}, \square)(\mathrm{V}, \mathrm{Ti})_{3} \mathrm{O}_{6}$, un minéral découvert dans le gisement d'émeraude de Byrud, en Norvège, jusqu'à un résidu $R_{1}$ de $4.51 \%$ en utilisant 1413 réflexions uniques. La structure est orthorhombique, Pnma, avec les paramètres réticulaires $a 9.982(1), b$ 8.502(1), $c 4.5480(6) \AA, Z=4$, et isotypique de celle de la norbergite, $\mathrm{Mg}_{3} \mathrm{SiO}_{4} \mathrm{~F}_{2}$. La formule chimique empirique, fondée sur une détermination de la teneur en éléments plus lourds que l'oxygène, et le béryllium provisoirement fixé à un atome de Be pour six d'oxygène, serait $\mathrm{Be}\left(\mathrm{V}^{3+}{ }_{1.27} \mathrm{Ti}_{1.21} \mathrm{Cr}_{0.29} \mathrm{Fe}_{0.08} \mathrm{Al}_{0.07}\right)_{\Sigma 2.92} \mathrm{O}_{6}$. La présence de Be a été vérifiée au cours de la détermination de la structure et par analyse avec une microsonde ionique (SIMS). Le taux d'occupation du site Be serait 0.84(1), ce qui rend largement compte de l'excédent de Ti dans la formule empirique, en comparaison de la formule stoechiométrique $\mathrm{BeV}_{2} \mathrm{TiO}_{6}$. Toutefois, il n'y a aucune signe de mise en ordre de $\mathrm{V}$ et de $\mathrm{Ti}$ aux deux sites octaédriques uniques dans cette structure. La formule empirique corrigée serait $\left(\mathrm{Be}_{0.84} \square_{0.16}\right)\left(\mathrm{V}^{3+}{ }_{1.32} \mathrm{Ti}_{1.25} \mathrm{Cr}_{0.22} \mathrm{Fe}_{0.09} \mathrm{Al}_{0.07}\right)_{\Sigma 2.02} \mathrm{O}_{6}$. L'apparence du minéral, la dominance de $\mathrm{V}$ et Ti dans sa formule, et les données de diffraction $\mathrm{X}$ (méthode des poudres) correspondent à ce qui a été antérieurement proposé pour la kyzylkumite, supposée être $\mathrm{V}_{2} \mathrm{Ti}_{3} \mathrm{O}_{9}$. Les paramètres réticulaires proposés pour la kyzylkumite témoignent d'une supermaille $8 \times$, résultat d'une macle par réflexion sur $\{210\}$. Ce genre de macle est aussi caractéristique de notre minéral de Byrud, et il est aussi présent dans le cristal utilisé pour établir la structure. Ces faits font penser que la même sorte d'oxyde de Be, $\mathrm{V}$ et Ti découverte à Byrud est le composant principal du matériau décrit comme kyzylkumite, qui contient probablement des phases additionnelles. Il semble évident qu'une redéfinition de la kyzylkumite s'impose.

(Traduit par la Rédaction)

Mots-clés: kyzylkumite, $(\mathrm{Be}, \square)(\mathrm{V}, \mathrm{Ti})_{3} \mathrm{O}_{6}$, isotype de norbergite, série leucophoenicite-humite, structure cristalline, macle, oxyde de $\mathrm{V}-\mathrm{Ti}-\mathrm{Be}$, gisement d'émeraude de Byrud, Norvège.

$\S \quad$ E-mail address: gunnar.raade@nhm.uio.no 


\section{INTRODUCTION}

Kyzylkumite was described as a new mineral from Kyzylkum in Uzbekistan by Smyslova et al. (1981). A more detailed locality was given by Pekov (1998) as the Koscheka uranium deposit, Auminzatau Mountains, central Kyzylkum region. The results of the electronmicroprobe analyses correspond closely to $\mathrm{V}_{2} \mathrm{Ti}_{3} \mathrm{O}_{9}$, i.e., it has a polymorphic relationship with schreyerite. The mineral occurs as black grains up to $0.2 \mathrm{~mm}$ across in albitized carbonaceous-siliceous rocks and quartz veins, associated with chlorite, pyrite and rutile. Laue and oscillation photographs gave a monoclinic cell with $a$ 33.80(5), $b 4.578(5), c$ 19.99(3) $\AA, \beta$ 93.40(5) ${ }^{\circ}$, $Z=18$. The X-ray powder-diffraction pattern shows 19 measured reflections (the abstract in Am. Mineral. erroneously reports 23 reflections by including four reflections of schreyerite listed for comparison).

We have investigated a black mineral from the Byrud emerald mine, Akershus, Norway, which gives a powder pattern practically identical to that of kyzylkumite. It contains the same elements as kyzylkumite: major $\mathrm{Ti}$ and $\mathrm{V}$ and minor $\mathrm{Cr}$ and $\mathrm{Fe}$. However, the analytical total by electron-microprobe analysis is well below $100 \%$. By single-crystal determination of the structure on a twinned crystal, the missing element was found to be Be. The crystal structure shows that Be plays a distinct role in the structure and is an essential constituent of the Byrud mineral.

Our recent proposal to the IMA Commission on New Minerals and Mineral Names for a redefinition of kyzylkumite was commented on by 13 of the commission members. Six members were in favor of a redefinition and seven were against; four of the latter suggested that we describe the Byrud mineral as a new species. On the basis of these divergent opinions, we decided not to request a final vote on the proposal. Here, we present a full chemical and structural characterization of the mineral from Byrud.

\section{BACKGROUND INFORMATION}

For comparative purposes, it was essential to obtain a fragment of holotype kyzylkumite. Smyslova et al. (1981) stated that samples with grains of kyzylkumite are preserved in the Chernyshev Central ScientificResearch Geological-Prospecting Museum, in St. Petersburg, with catalogue number 11885. Unfortunately, our letter of 5 October 2004 to the museum has so far remained unanswered.

According to Pekov (1998), type material of kyzylkumite is housed in the Mining Museum of St. Petersburg Mining Institute (catalogue number 1197/1) and in the Mineralogical Museum, St. Petersburg University (catalogue number 17408). We have been in contact with both institutions, but they have declined to send us material owing to the very small amounts available.
Thus, although the whole idea of keeping type material in professionally curated museums is to make material available for study to bona fide researchers, we have not been able to access samples this way, and our efforts to make a comparison of the Byrud mineral with the kyzylkumite type-material must remain incomplete.

We have been referred to two people who might have material from the type locality. One of them, Dr. M.N. Murashko, has made some material claimed to originate from the authors of the kyzylkumite description available to us. The material consisted of nine polished mounts, containing two, three or four grains [which we have examined by electron-microprobe analysis in wavelength-dispersion (WDS) mode], and 46 single grains [which we have examined by energydispersion spectrometry (EDS) in a scanning electron microscope). These inhomogeneous, multiphase grains mainly consist of $\mathrm{TiO}_{2}$ (rutile?) with varying amounts of $\mathrm{V}, \mathrm{Fe}$ and Ta. Grains of quartz, K-feldspar, apatite and pyrite also were detected. One polished mount that we received from Dr. Murashko (on loan from his collection) turned out to contain a grain chemically identical to another tiny, mounted grain of alleged kyzylkumite that we had previously purchased from mineral dealer S. Möckel (see under Chemical Data).

\section{The Byrud EMERALD DePosit}

The emerald deposit at Byrud, in Eidsvoll, Akershus, southern Norway, is located in the northeastern part of the Permian rift structure of the Oslo Region. It was discovered in the 1860s and mined in the period 1899-1909 by an English company. The emerald mineralization is connected to syenitic pegmatites transecting Cambrian black shales and sills of Permian maenaite (a calcic bostonite). Vanadium is the main chromophore in the emerald; the $\mathrm{V}_{2} \mathrm{O}_{3}$ content ranges from 0.88 to 1.53 wt.\%, whereas $\mathrm{Cr}_{2} \mathrm{O}_{3}$ ranges from 0.10 to 0.32 wt.\% (Schwarz 1991). The elements $\mathrm{V}$ and $\mathrm{Cr}$ are considered to originate by the assimilation of black shale.

Close to 45 different minerals have been recorded from the Byrud deposit. Tiny, black grains are common as inclusions in feldspar and quartz. Most of them turn out to be tantalian and niobian rutile ("strüverite" "ilmenorutile"). Also, V-rich $\mathrm{TiO}_{2}$ (rutile?) with varying amounts of $\mathrm{Nb}$ and $\mathrm{Ta}$ has been found, the $\mathrm{V}$ content, expressed as $\mathrm{V}_{2} \mathrm{O}_{3}$, varying from 6.01 to $9.41 \mathrm{wt}$.\%. A balanced empirical formula requires that most of the vanadium be present in the tetravalent state. Some rare grains, also black and opaque, turned out to have an $\mathrm{X}$ ray powder-diffraction diagram nearly identical to that of kyzylkumite. Visually, they are not easily distinguishable from the rutile varieties. They occur as prismatic, needle- or lath-shaped crystals, rarely exceeding $1 \mathrm{~mm}$ in length. Polysynthetic twins cause striations in some crystals (Fig. 1). It should be noted that kyzylkumite also is described as showing twin striations along the axis of elongation (Smyslova et al. 1981). 


\section{Chemical Data}

The crystal fragment of the Byrud mineral used for structure determination, with a polished surface $c a$. $0.2 \times 0.1 \mathrm{~mm}$, was analyzed with a Cameca SX100 electron microprobe in WDS mode, operated at $15 \mathrm{kV}$ and $10 \mathrm{nA}$, with a focused electron beam. Care was taken to avoid interferences involving $\mathrm{Ti}, \mathrm{V}$ and $\mathrm{Cr}$. The following standards and peaks were used: $\mathrm{Al}_{2} \mathrm{O}_{3}$ $(\mathrm{A} 1 K \alpha)$, vanadinite $(\mathrm{V} K \alpha), \mathrm{Cr}_{2} \mathrm{O}_{3}(\mathrm{Cr} K \beta), \mathrm{Fe}_{2} \mathrm{O}_{3}$ $(\mathrm{Fe} K \alpha)$ and pyrophanite $(\mathrm{Ti} K \alpha)$. Substantial amounts of $\mathrm{Be}$ and trace amounts of $\mathrm{Li}$ were detected by SIMS analysis, but could not be quantified owing to the lack of proper standards.

The mean result of six electron-microprobe analyses is given in Table 1. Here, $\mathrm{BeO}$ is, as a first approximation, calculated to give one $\mathrm{Be}$ for $\mathrm{O}=6$. The resulting empirical formula, based on $\mathrm{O}=6$, is: $\mathrm{Be}_{1.00}\left(\mathrm{~V}^{3+}{ }_{1.27}\right.$ $\left.\mathrm{Ti}_{1.21} \mathrm{Cr}_{0.29} \mathrm{Fe}_{0.08} \mathrm{Al}_{0.07}\right)_{\Sigma 2.92} \mathrm{O}_{6.00}$. Reducing Be to 0.84, in accordance with the result of the crystal-structure refinement, gives the following empirical formula: $\left(\mathrm{Be}_{0.84} \square_{0.16}\right)\left(\mathrm{V}^{3+}{ }_{1.32} \mathrm{Ti}_{1.25} \mathrm{Cr}_{0.29} \mathrm{Fe}_{0.09} \mathrm{Al}_{0.07}\right)_{\Sigma 2.02} \mathrm{O}_{6.00}$.

The idealized formula of the mineral is $\mathrm{Be}^{2+} \mathrm{V}_{2}{ }^{3+}$ $\mathrm{Ti}^{4+} \mathrm{O}_{6}$ (Balić-Žunić \& Raade 2003). The observed discrepancy from the ideal formula (surplus of Ti) can to a large extent be explained by the vacancy at the tetrahedral Be site, that is, $2^{\mathrm{VI}}(\mathrm{V}, \mathrm{Cr}, \mathrm{Fe})^{3+}+{ }^{\mathrm{IV}} \mathrm{Be}^{2+}$
$=2{ }^{\mathrm{VI}} \mathrm{Ti}^{4+}+{ }^{\mathrm{IV}} \square$. The presence of some ferrous iron, according to the substitution scheme $\mathrm{Fe}^{2+}+\mathrm{Ti}^{4+}=2 \mathrm{~V}^{3+}$, could also contribute to the surplus of $\mathrm{Ti}$, but only to a small degree owing to the limited amount of Fe present in the mineral.

The mean result of five WDS analyses of a grain of alleged kyzylkumite that we purchased from S. Möckel also is given in Table 1 (a nearly identical result was obtained on the grain we received from Dr. Murashko). The analytical total is only $94.07 \mathrm{wt} . \%$. It is important to note that an ion-microprobe (SIMS) analysis of this grain showed minor amounts of $\mathrm{Be}$ and traces of $\mathrm{Li}$. The incomplete analytical results in Table 1 can be tentatively calculated on $\mathrm{O}=24$ to give the empirical formula $\left(\mathrm{V}^{3+}{ }_{3.58} \mathrm{Cr}_{0.25} \mathrm{Fe}_{0.19} \mathrm{Al}_{0.01}\right)_{\Sigma 4.03} \mathrm{Ti}_{8.98} \mathrm{O}_{24}$. However, a formula similar to that of the Byrud mineral can be written for this sample assuming sufficient Be for the octahedral cations to total 3. This assumption gives a reasonable analytical total: $\mathrm{BeO} 4.70, \mathrm{Al}_{2} \mathrm{O}_{3}$ 0.06, $\mathrm{V}_{2} \mathrm{O}_{3}$ 24.71, $\mathrm{Cr}_{2} \mathrm{O}_{3}$ 1.72, $\mathrm{Fe}_{2} \mathrm{O}_{3}$ 1.37, $\mathrm{TiO}_{2} 66.21$, total 98.77 wt.\%. The resulting empirical formula is $\mathrm{Be}_{0.47}\left(\mathrm{Ti}_{2.07} \mathrm{~V}^{3+}{ }_{0.82} \mathrm{Cr}_{0.06} \mathrm{Fe}_{0.04}\right)_{\Sigma 2.99} \mathrm{O}_{6.00}$.

We have not been able to demonstrate the presence of a mineral from Kyzylkum with the formula $\mathrm{V}_{2} \mathrm{Ti}_{3} \mathrm{O}_{9}$, corresponding to the original analytical data reported for kyzylkumite (included in Table 1). Differences in analytical data for the mineral from Byrud and the other

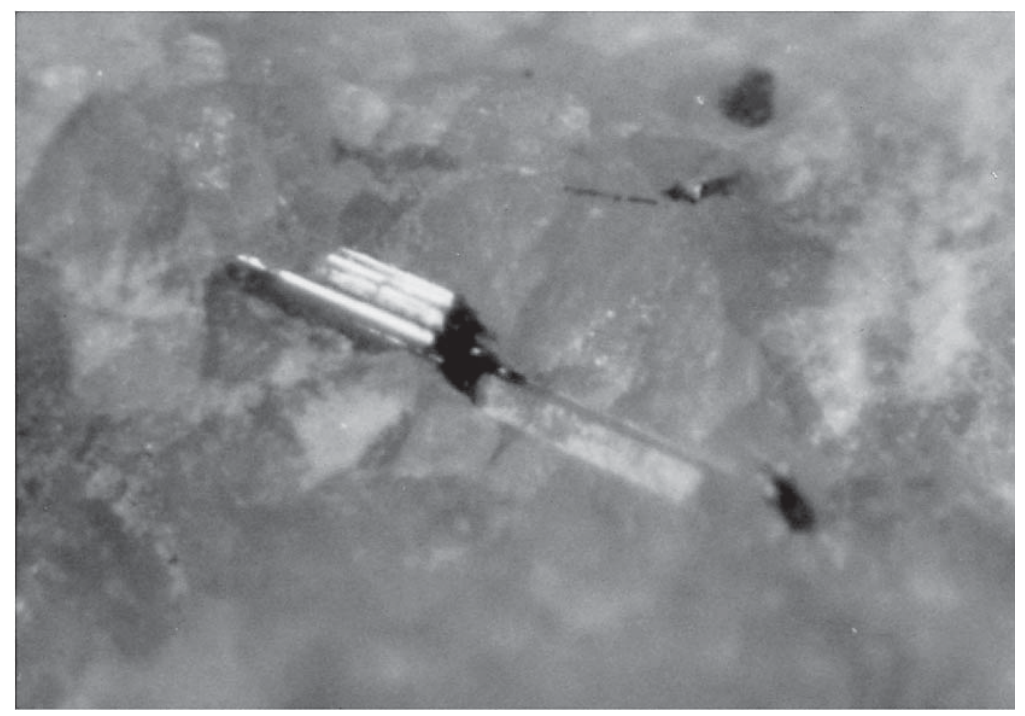

FIG. 1. A polysynthetically twinned crystal of $(\mathrm{Be}, \square)(\mathrm{V}, \mathrm{Ti})_{3} \mathrm{O}_{6}$ from Byrud, embedded in quartz which is surrounded by K-feldspar. The original length was in excess of $1 \mathrm{~mm}$. The picture shows the crystal after somewhat more than half of it had been sacrificed for X-ray powder diffractometry. Most of the remaining fragment shown in the picture was later used for crystal-structure determination and EMP analyses. Photo by O.T. Ljøstad. 
samples (especially as regards the proportions of Ti and trivalent elements) remain an unsolved problem. More light on this will only be shed by a renewed, detailed chemical and structural analysis of type kyzylkumite.

\begin{tabular}{|c|c|c|c|}
\hline & \multirow{2}{*}{$\begin{array}{c}\text { Byrud } \\
\text { mean of } 6\end{array}$} & \multicolumn{2}{|c|}{ Koscheka } \\
\hline & & $\begin{array}{l}\text { Möckel* } \\
\text { mean of } 5\end{array}$ & $\begin{array}{l}\text { Kyzylkumite } \\
\text { Snyslova } \\
\text { et al. (1981) }\end{array}$ \\
\hline $\mathrm{BeO}^{*}$ & $9.92^{+}$ & & \\
\hline $\mathrm{Al}_{2} \mathrm{O}_{3}$ & 1.44 & 0.06 & \\
\hline $\mathrm{V}_{2} \mathrm{O}_{3}^{\mathrm{t}}$ & 37.86 & 24.71 & 36.2 \\
\hline $\mathrm{Cr}_{2}^{4} \mathrm{O}_{3}$ & 8.79 & 1.72 & 1.2 \\
\hline $\mathrm{Fe}_{2} \mathrm{O}_{3}$ & 2.66 & 1.37 & 0.7 \\
\hline $\mathrm{TiO}_{2}$ & 38.36 & 66.21 & 61.7 \\
\hline Total & 99.03 & 94.07 & 99.8 \\
\hline
\end{tabular}

* Sample of alleged kyzylkumite purchased from mineral dealer S. Möckel \$ Calculated to give $\mathrm{lBe}$ for $\mathrm{O}=6$. $\mathrm{BeO}$ is $8.04 \mathrm{wt} \%$ if $\mathrm{Be}$ is reduced to $0.84 \mathrm{apft}$ as indicated by the structure solution. and the total becomes $97.15 \mathrm{w1} . \%$

analyzed with $K \alpha_{\text {l }}$ in the furst two cases; Snyslova et al, used $K \beta$.

TABLE 2. X-RAY POWDER-DIFFRACTION DATA OF THE BYRLD MINERAI AND KYZYL KUMITE

\begin{tabular}{|c|c|c|c|c|}
\hline \multicolumn{3}{|c|}{$\begin{array}{l}\text { Mineral from Byrud } \\
\text { (calculated)* }\end{array}$} & \multicolumn{2}{|c|}{$\begin{array}{l}\text { Kyzylkumite } \\
\text { Snyslova et al. (1981 }\end{array}$} \\
\hline$h k l$ & $d(\AA)$ & $I / I_{0}$ & $d(\AA)$ & $1 / I_{0}$ \\
\hline [0] & 4.142 & 16 & 4.15 & 25 \\
\hline 111 & 3.724 & 69 & 3.70 & 80 \\
\hline 121 & 2.967 & 100 & 2.92 & 100 \\
\hline 301 & 2.687 & 19 & & \\
\hline 311 & 2.563 & 47 & 2.60 & 50 \\
\hline 400 & 2.497 & 14 & 2.510 & 40 \\
\hline 230 & 2.466 & 31 & 2.495 & 30 \\
\hline 131 & 2.340 & 14 & 2.39 & 5 \\
\hline 002 & 2.276 & 5 & & \\
\hline 321 & $2.272)$ & 21 & 2.310 & 15 \\
\hline 401 & 2.189 & 17 & 2.203 & 45 \\
\hline \multirow[t]{2}{*}{231} & 2.168 & 31 & 2.192 & 48 \\
\hline & & & 2.115 & 24 \\
\hline 141 & 1.892 & 10 & & \\
\hline 402 & $1.682\}$ & 33 & 1.692 & 50 \\
\hline 521 & $1.681)$ & 15 & & \\
\hline \multirow[t]{2}{*}{232} & 1.672 & 72 & 1.682 & 65 \\
\hline & & & 1.650 & 55 \\
\hline 151 & 1.574 & 12 & 1.577 & 25 \\
\hline 620 & 1.550 & 5 & & \\
\hline 531 & 1.537 & 11 & & \\
\hline 351 & 1.438 & 13 & & \\
\hline 630 & 1.436 & 24 & 1.469 & 20 \\
\hline 060 & 1.418 & 15 & $1.415-1.395$ & 20 \\
\hline 123 & $|.414|$ & 7 & & \\
\hline 313 & $1.363 !$ & 8 & 1.372 & 15 \\
\hline 701 & $\mid .362\}$ & 6 & 1.360 & 15 \\
\hline 233 & 1.292 & 5 & & \\
\hline
\end{tabular}

* Calculated with the program PowdereCell 2.0 beta for the ideal composition $\mathrm{BeV}_{2} \mathrm{TiO}_{6}\left(\mathrm{CuK \alpha _{1 }}\right.$ radiation, Bragg-Brentano geometry).

\section{X-RAY POWDER-Diffraction DATA}

Owing to paucity of material, we have only a few weak X-ray powder-diffraction photographs of the Byrud mineral, obtained with a 9-cm Debye-Scherrer camera, using $\mathrm{Fe} K \alpha$ radiation. The strongest reflections ( $d$ values in $\AA$ ) occur at 4.15 (weak), 3.72 (medium), 2.96 (strong), 2.57 (weak), 2.48 (very weak), 2.32 (very weak), 2.17 (weak), 1.68 (strong, broad) and 1.43 (weak). This pattern corresponds well with the one published for kyzylkumite by Smyslova et al. (1981).

A calculated X-ray powder-diffraction pattern for the Byrud mineral, based on the present refinement of its structure, is given in Table 2 and compared to the pattern published for kyzylkumite. The small discrepancies between the two powder patterns can be explained by contamination in the kyzylkumite pattern (extra reflections at 2.115 and $1.650 \AA$ ). Unfortunately, we could not obtain X-ray powder-diffraction data on our analyzed sample of alleged kyzylkumite from Uzbekistan.

\section{Solution OF THE CRYstal StRUCTURE}

A small, lath-like crystal with irregular boundaries, $0.31 \times 0.14 \times 0.05 \mathrm{~mm}$ in size, was chosen for the structure determination. It was mounted on a Bruker AXS diffractometer with a four-circle goniometer and a SMART 1000 CCD detector. Further data on crystal and measurements are presented in Table 3.

The SMART software (Bruker AXS 1998) was used for the cell determination and data collection, and SAINT+ (Bruker AXS 2003a) for the multicomponent integration of intensities, Lorentz-polarization correction and calculation of the final unit-cell parameters. For an empirical absorption-correction, the program TwINABS (Bruker AXS 2003b) was used. The complex appearance of the reciprocal lattice suggested a twin. Using the program GEMINI (Bruker AXS 1999), the

TABLE 3. CRYSTAL AND MEASUREMENT DATA FOR $(\mathrm{Be}, \square)(\mathrm{V}, \mathrm{Ti})_{3} \mathrm{O}_{6}$

\begin{tabular}{|c|c|}
\hline Formula weight, $M_{r}$ & 249.10 \\
\hline Crystal system & Orthorhombic \\
\hline Space group (No.) & Prmal (62) \\
\hline$a(\AA)$ & $9.982(1)$ \\
\hline$b(\AA)$ & $8.502(1)$ \\
\hline$c(A)$ & $4.5480(6)$ \\
\hline$V\left(\AA^{3}\right)$ & $385.97(9)$ \\
\hline$z$ & 4 \\
\hline$F(000)$ & 478 \\
\hline$\mu\left(\mathrm{mm}^{\prime}\right)$ & $6.78 \mathrm{I}$ \\
\hline$\rho_{x}\left(\mathrm{~g} \mathrm{~cm}^{-3}\right)$ & 4.381 \\
\hline Range for data collection, $\theta\left({ }^{\circ}\right)$ & $4.08-29.64$ \\
\hline Limiting indices & $\begin{array}{l}-13 \leq h \leq 13,-11 \leq k \leq 11, \\
-6 \leq l \leq 6\end{array}$ \\
\hline Reflections collected/unique & $5881 / 1413\left(R_{i, y}=0.0209\right)$ \\
\hline Data / restraints / parameters & $1413 / 0 / 54$ \\
\hline Goodness-of-fit. $S$ & 0.830 \\
\hline$R$ indices $[I>2 \sigma(I)]$ & $R_{i}=0.0451, w R_{z}=0.1192$ \\
\hline$R$ indices (all data) & $R_{1}=0.0693, w R_{2}=0.1353$ \\
\hline
\end{tabular}

${ }^{*}=1 /\left[\sigma^{2}\left(F_{o}^{2}\right)+(0.1 P)^{2}\right]$, where $P=\left(F_{o}^{2}+2 F_{c}^{2}\right) / 3$ 
lattice dimensions and orientations of two orthorhombic twin components were found, with $\{210\}$ as the twin plane. The program suggested a $B$-centered lattice in accordance with the strongest reflections chosen for the lattice determination. An attempt at solving the structure using this lattice did not give a satisfactory result, because only the heaviest atoms (V and $\mathrm{Ti}$ ) are arranged according to a $B$-centered lattice, whereas the full symmetry of the structure is based on an orthorhombic $P$ lattice. We then realized that the lattice parameters resemble very much those of norbergite; the space group of norbergite, Pnma, also was checked, and a number of weaker reflections conforming to this space group were found. Structure solution in Pnma was straightforward, and confirmed the isotypy with norbergite, ideally $\mathrm{Mg}_{3} \mathrm{SiO}_{4} \mathrm{~F}_{2}$.

The structure was solved by direct methods, using only the non-overlapping reflections of the main component of the twin. The positions of $\mathrm{V}, \mathrm{Ti}$ and $\mathrm{O}$ could be determined among the main peaks of a sharpened Fourier synthesis. An inspection of the structure model revealed the presence of a tetrahedrally coordinated cation, and the peak in the $F_{\mathrm{o}}$ Fourier synthesis suggested it to have about four electrons. In this way, the presence of $\mathrm{Be}$ in the structure was recognized for the first time and later confirmed by SIMS. Initially, we had also anticipated the possible presence of $\mathrm{Be}$ as the missing element in the chemical analysis from the association with beryl.

In a subsequent refinement of the structure, all integrated reflections (both non-overlapping and overlapping) of the two twin components were used. For structure solution and refinement, the programs SHELXS97 (Sheldrick 1997a) and SHELXL97 (Sheldrick 1997b) were used. In the final cycles of refinement, all atoms were refined with anisotropic displacement factors. The refined proportions of the two twin components are 62.9(1):37.1(1).

Beryllium, which occupies the tetrahedral site, was refined with a free occupancy-parameter, whereas the scattering factor of the octahedrally coordinated cations was defined as a combination of $\mathrm{V}$ and $\mathrm{Ti}$ in proportion $1: 1$. This is in accordance with the results of the chemical analysis, from which the average number of electrons for octahedrally coordinated cations was calculated to be 22.5. Moreover, a crystal-chemical

TABLE 4. ATOM PARAMETERS IN THE STRUCTURE OF (Be, घ) (V.Ti); $\mathrm{O}_{6}$

\begin{tabular}{llllll}
\hline Aton & \multicolumn{1}{c}{$x$} & \multicolumn{1}{c}{$y$} & \multicolumn{1}{c}{$z$} & \multicolumn{1}{c}{$U_{\text {cr }}$} & Occupancy \\
\hline $\mathrm{Be}$ & $0.2803(4)$ & 0.75 & $0.0751(7)$ & $0.013(1)$ & $0.84(1)$ \\
$(\mathrm{V}, \mathrm{Ti})_{1}$ & $0.40497(4)$ & 0.25 & $0.00773(8)$ & $0.0073(1)$ & $0.5 \mathrm{~V}+0.5 \mathrm{Ti}$ \\
$(\mathrm{V}, \mathrm{Ti})_{2}$ & $0.12914(2)$ & $0.43081(3)$ & $0.00440(6)$ & $0.0070(1)$ & $0.5 \mathrm{~V}+0.5 \mathrm{Ti}$ \\
$\mathrm{O}$ & $0.2204(2)$ & 0.25 & $0.2255(3)$ & $0.0066(3)$ & 1 \\
$\mathrm{O} 2$ & $0.4336(2)$ & 0.75 & $0.2396(3)$ & $0.0089(4)$ & 1 \\
03 & $0.4650(1)$ & $0.4147(1)$ & $0.2669(2)$ & $0.0087(3)$ & 1 \\
04 & $0.2064(1)$ & $0.5951(1)$ & $0.2511(2)$ & $0.0093(3)$ & 1 \\
\hline
\end{tabular}

analysis (see below) suggests that $\mathrm{V}$ and $\mathrm{Ti}$, which dominate among the octahedral cations, are randomly distributed over two unique octahedral sites.

The largest residual electron-densities $\left(2.06 e / \AA^{3}\right)$ were found at the center of the empty octahedra in the structure. They can be a consequence of the expected structural defects (see the following discussion).

The final atom-parameters are presented in Table 4. The table of anisotropic atomic displacement-factors may be obtained from the Depository of Unpublished Data, CISTI, National Research Council of Canada, Ottawa, Ontario K1A 0S2, Canada.

\section{DesCrIPTION OF THE CRYstal StruCture}

The crystal structure reveals that $\mathrm{Be}$ is an essential constituent, together with $\mathrm{V}$ and $\mathrm{Ti}$, and that the mineral is isostructural with norbergite, $\mathrm{Mg}_{3} \mathrm{SiO}_{4} \mathrm{~F}_{2}$. The previously determined lattice parameters of kyzylkumite (Smyslova et al. 1981), which gave a unit cell eight times larger, are obviously due to the unrecognized twinning that is common in this mineral, as described below.

The structure (Fig. 2) comprises one tetrahedrally coordinated and two independent, octahedrally coordinated cation sites. In accordance with the bond distances and a low electron-density, the tetrahedral site hosts Be. The atomic displacement factor at this site is significantly higher than for any other site in the structure, and it was therefore refined with a free occupancy-parameter

TABLE 5. BOND DISTANCES, ANGLES AND OTHER COORDINATION PARAMETERS FOR CATIONS IN $(\mathrm{Be}, \square)\left(\mathrm{V}, \mathrm{Ti}_{3}\right)_{6}$

\begin{tabular}{|c|c|c|c|c|c|c|}
\hline$(\mathbf{V}, \mathbf{T i})_{1}$ & 03 & 03 & 02 & O4 & O4 & 01 \\
\hline 03 & $1.926(1)$ & $93.3(1)$ & $95.5(1)$ & $165.8(0)$ & $92.8(0)$ & $89.1(0)$ \\
\hline $\mathrm{O3}$ & $2.801(2)$ & $1.926(1)$ & $95.5(1)$ & $92.8(0)$ & $165.8(0)$ & $89.1(0)$ \\
\hline $\mathrm{O} 2$ & $2.880(2)$ & $2.880(2)$ & $1.965(2)$ & $96.7(0)$ & $96.7(0)$ & $173.3(1)$ \\
\hline 04 & $3.977(2)$ & $2.905(2)$ & $3.026(2)$ & $2.082(1)$ & $78.5(1)$ & $78.2(0)$ \\
\hline 04 & $2.905(2)$ & $3.977(2)$ & $3.026(2)$ & $2.634(2)$ & $2.082(1)$ & $78.2(0)$ \\
\hline 01 & $2.821(2)$ & $2.821(2)$ & $4.051(2)$ & $2.631(2)$ & $2.631(2)$ & $2.092(2)$ \\
\hline$\langle\mathrm{d}\rangle=2.0 \mathrm{I}(8)$ & $r_{s}=2.010$ & 2). $\sigma=0$. & 199, $\Delta=0$ & $0.06, \quad V_{p}=$ & $=10.62(1)$ & $v=0.01$ \\
\hline$(\mathrm{V}, \mathrm{Ti})_{2}$ & 03 & $\mathrm{o} 3$ & 04 & $\mathrm{O} 4$ & O1 & $\mathrm{O} 2$ \\
\hline 03 & $1.943(1)$ & $86.4(1)$ & $91.5(0)$ & $98.60(0)$ & $173.9(0)$ & $91.9(0)$ \\
\hline o3 & $2.662(1)$ & $1.946(1)$ & $94.4(0)$ & $169.4(0)$ & $93.4(0)$ & $90.2(0)$ \\
\hline $\mathrm{O} 4$ & $2.790(2)$ & $2.858(2)$ & $1.951(1)$ & $94.9(1)$ & $94.5(0)$ & $174.4(0)$ \\
\hline 04 & $3.003(2)$ & $3.946(2)$ & $2.923(1)$ & $2.017(1)$ & $80.6(0)$ & $80.3(0)$ \\
\hline 01 & $3.987(2)$ & $2,909(2)$ & $2.940(1)$ & $2.631(2)$ & $2.050(1)$ & $82.0(0)$ \\
\hline $\mathrm{O} 2$ & $2.870(1)$ & $2.833(2)$ & $3.997(1)$ & $2.623(2)$ & $2.692(2)$ & $2.051(1)$ \\
\hline$\langle\mathrm{d}\rangle=1.99(5)$ & $\mathrm{r}_{\mathrm{s}}=1.990$ & 1), $\sigma=0$. & $99, \quad \Delta=0$ & $0.04, \quad V_{p}=$ & $=10.39(1)$ & $v=0.01$ \\
\hline Be & O! & $\mathrm{O} 2$ & 04 & 04 & & \\
\hline OI & $1.590(3) 1$ & $116.3(2)$ & $117.8(2)$ & $117.8(2)$ & & \\
\hline $\mathrm{O} 2$ & $2.798(2)$ & $1.703(4)$ & $100.5(2)$ & $100.5(2)$ & & \\
\hline 04 & $2.825(2)$ & $2.623(2)$ & $1.708(3)$ & $100.9(2)$ & & \\
\hline 04 & $2.825(2)$ & $2.623(2)$ & $2.634(2)$ & $1.708(3)$ & & \\
\hline$\langle d\rangle=1.68(6)$ & $r_{s}=1.67$ & $1, \quad \sigma=1$ & 00, $\Delta=0$ & $0.05, \quad V_{p}=$ & $=2.36(\mathrm{I})$ & $y=0.0 \mathrm{~J}$ \\
\hline
\end{tabular}
(Balić-Ž̉nić \& Vicković 1996). 


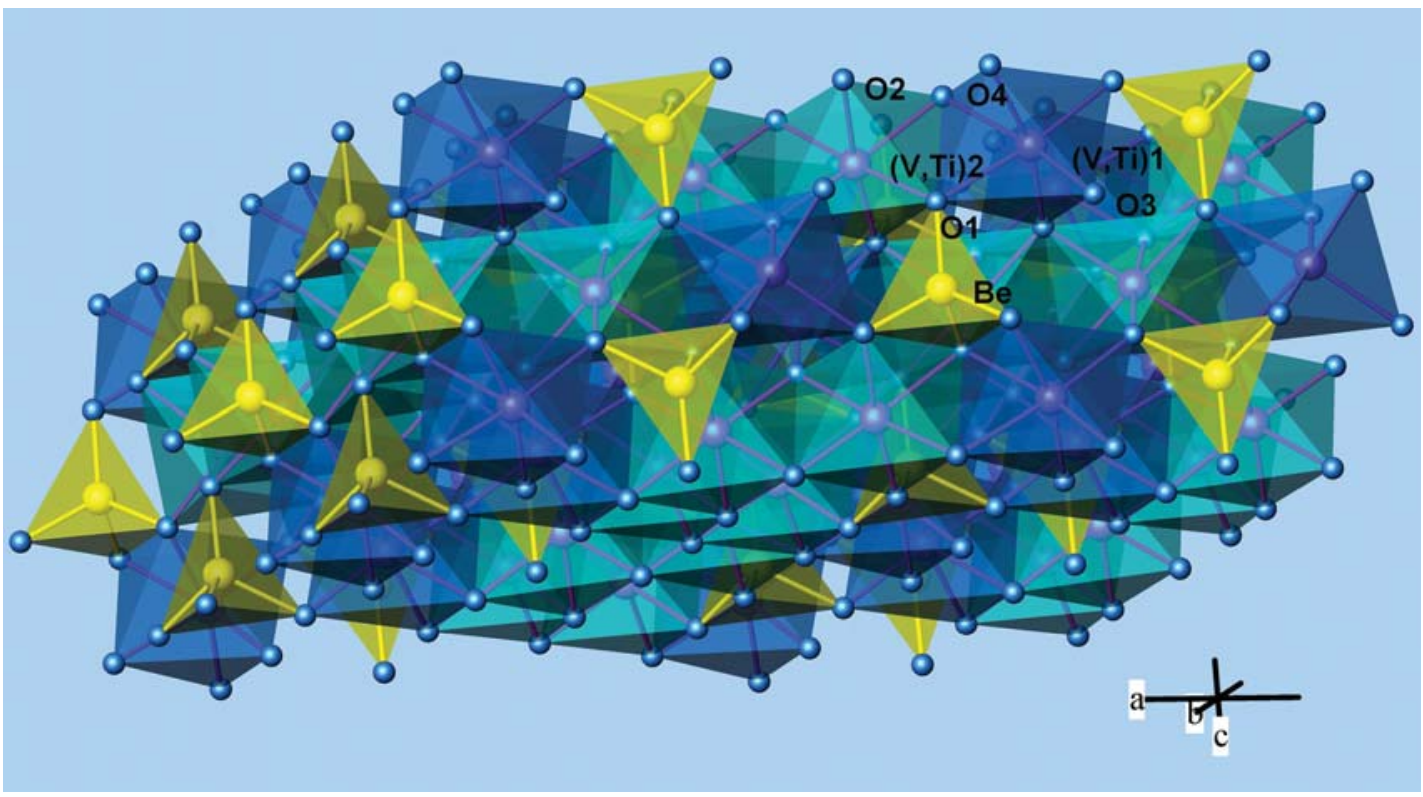

Fig. 2. Projection of the crystal structure of $(\mathrm{Be}, \square)(\mathrm{V}, \mathrm{Ti})_{3} \mathrm{O}_{6}$. The coordination tetrahedra of Be are yellow, coordination octahedra of $(\mathrm{V}, \mathrm{Ti})$ are blue (dark blue for site 1, greenish blue for site 2). The orientation of the crystallographic axes and labels of atoms in one asymmetric unit are indicated.

in the last stage. The results suggest $16(1) \%$ vacancies at this site. If $\mathrm{Be}$ is replaced by a lighter element, the only candidate would be Li, which is known to occur in fourfold as well as in sixfold coordination with oxygen. The small quantities of Li registered by SIMS could well be incorporated in the tetrahedral site.

The tetrahedral configuration of oxygen atoms is almost completely regular, shown by a low volumedistortion (Table 5), whereas the central atom is moderately eccentric and moved toward the vertex along the [001] direction, forming one short (1.59 $\AA$ ) and three long (1.70-1.71 $\AA$ ) bonds. The size of the Be coordination is somewhat larger than the equivalent ones found in asbecasite (Sacerdoti et al. 1993) and odintsovite (Rastsvetaeva et al. 1995), which both have smaller volumes of tetrahedra $\left(2.18-2.20 \AA^{3}\right.$, compared to $2.36 \AA^{3}$ found in the present structure). The larger tetrahedron can be a consequence of vacancies at the Be site or some substitution by Li, but it is not far from the value of $2.30 \AA^{3}$ calculated for the Be tetrahedron in $\mathrm{BeO}$ (Hazen \& Finger 1986).

One of the octahedral sites occupies a special position $\left(\mathrm{C}_{\mathrm{s}}\right.$ symmetry), whereas the other is at a general position. The coordination polyhedron of the former has a slightly larger volume (2\%), as is characteristic for almost all other isostructural compounds with the exception of $\mathrm{NbNi}_{2} \mathrm{BO}_{6}$, where the opposite situation occurs (Table 6). In both octahedral coordination poly- hedra, the central atom forms three shorter (1.93-1.96 $\AA$ ) and three longer (2.02-2.09 $\AA$ ) bonds, because it is moved from the center toward one of the faces of the octahedron. The octahedra are almost regular, as indicated by high sphericities and low volume-distortions, whereas the eccentricity of the central atom is moderate (Table 5).

It is difficult to conclude whether there is any site preference involving the octahedral cations in the Byrud mineral. Very small differences in the bond distances for the two octahedral sites, which both are in the ranges typical for $\mathrm{V}, \mathrm{Ti}$ and $\mathrm{Cr}$, suggest that these elements most probably are randomly distributed over the two sites. The majority of isostructural compounds have the same cation on both sites (Table 6). On the other hand, in an idealized formula, $\mathrm{Be} M^{4+} M_{2}{ }^{3+} \mathrm{O}_{6}$, the proportions of $\mathrm{M}^{4+}$ and $\mathrm{M}^{3+}$ atoms correspond to the multiplicities of the first and the second site, respectively, and it is tempting to assume a distribution of $\mathrm{Ti}^{4+}$ and $(\mathrm{V}, \mathrm{Cr})^{3+}$ in accordance with this finding. There are two factors that detract from such an inference. Consider first the relative size of the two coordination polyhedra. It is true that in a series of the mixed-cation compounds $(\mathrm{V}, \mathrm{Ti})_{2} \mathrm{O}_{3}$ (Rice \& Robinson 1977) and (V,Cr) ${ }_{2} \mathrm{O}_{3}$ (Reid et al. 1972), the pure $\mathrm{V}$ compound has an octahedron volume of $10.66 \AA^{3}$, whereas $\mathrm{VTiO}_{3}$ has $10.93 \AA^{3}$ and $\mathrm{CrVO}_{3}$ has $10.50 \AA^{3}$. Thus, replacement of V by Ti introduces a small increase in volume, whereas the replacement 


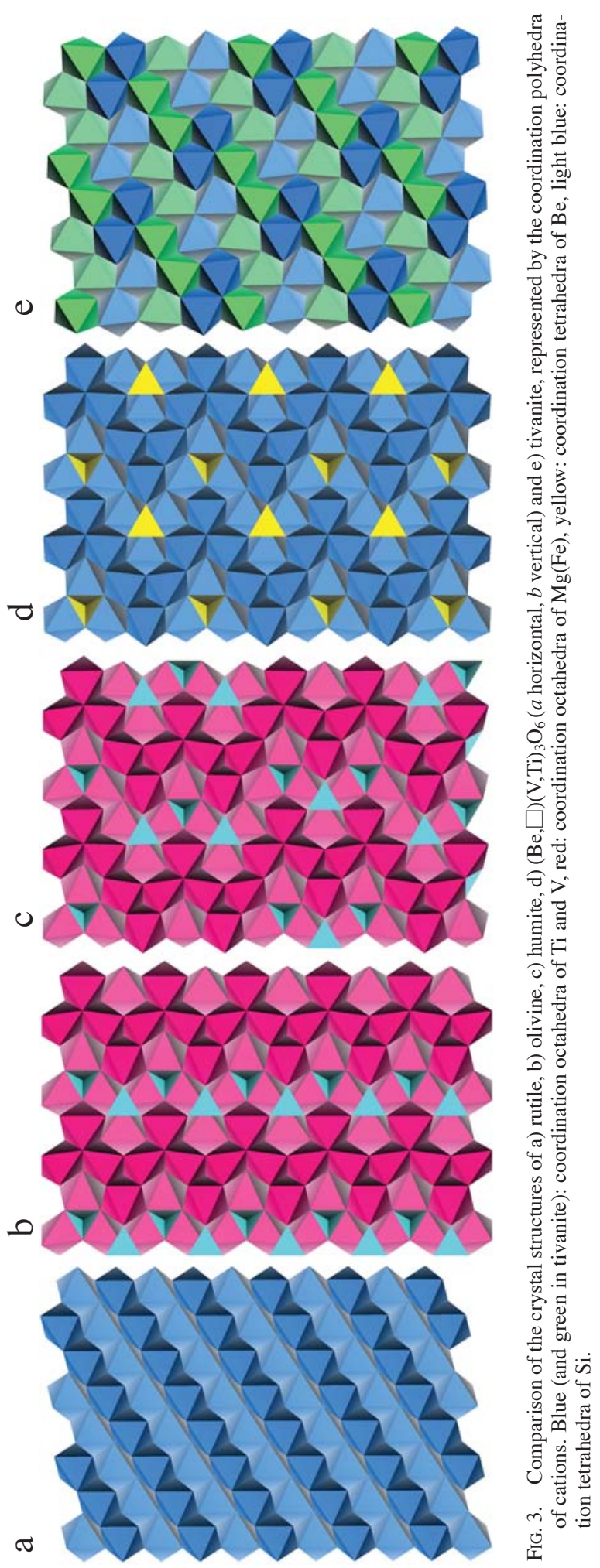


of $\mathrm{V}$ by $\mathrm{Cr}$ produces a slight decrease. However, $\mathrm{Ti}$ in the Byrud mineral is expected to be tetravalent and not trivalent as in $(\mathrm{V}, \mathrm{Ti})_{2} \mathrm{O}_{3}$, and the octahedron volume for $\mathrm{Ti}$ in $\mathrm{TiO}_{2}$ with the rutile structure $\left(9.89 \AA^{3}\right.$; Sugiyama \& Takeuchi 1991) is smaller than the volume of the $\mathrm{V}^{3+}-\mathrm{O}$ octahedron. Therefore, if some order of cations occurs in the present structure, one would expect V, and not $\mathrm{Ti}$, to concentrate in the larger octahedral site.

Consider next the relatively large deviation from an $1: 2$ ratio of $\mathrm{Ti}^{4+}: M^{3+}$ in the structure. Lacking any further evidence for the order of octahedral cations, a 1:1 proportion of $\mathrm{V}$ and $\mathrm{Ti}$ on both sites was used in the crystal-structure refinement, which gives 22.5 electrons on average, in accordance with full occupancy of both sites and the proportion of cations $\left(\mathrm{V}_{1.30} \mathrm{Ti}_{1.24} \mathrm{Cr}_{0.30}\right.$ $\left.\mathrm{Fe}_{0.08} \mathrm{Al}_{0.08}\right)$ calculated from the electron-microprobe data for three full octahedral sites per formula unit.

We conclude that a satisfactory refinement of the structure was obtained assuming a disordered distribution of octahedral cations, but it is not possible to give a definite answer on their distribution in the octahedral sites from the available X-ray-diffraction data because the scattering powers of $\mathrm{Ti}, \mathrm{V}$ and $\mathrm{Cr}$ are very similar, as well as the sizes of their respective coordination-polyhedra.

The crystal structure is based on a close to hexagonal eutaxy of oxygen atoms, with cations occupying $1 / 2$ of the available octahedral voids and 1/12 of the tetrahedral voids, where equal numbers of tetrahedra pointing up and down are present (Fig. 3d). The eutactic layers are parallel to (001). Octahedra share edges and form kinked chains along [010]. The straight segments of chains comprise four octahedra, with the octahedra with $\mathrm{C}_{\mathrm{s}}$ symmetry located on end positions, and the octahedra of the second type located at the two inner positions of segments. At each kink, a tetrahedron connects the two parallel chains inside the same (001) layer. The chains from adjacent layers share edges of octahedra, and are displaced relative to each other by $1 / 2$ [100] period, so that they exactly underlie the empty spaces between the parallel chains of the adjacent layer.

The Byrud mineral belongs to a structural family characterized by a modification of the general rutile motif of straight chains of edge-sharing octahedra into zig-zag chains (Fig. 3). The periods of zig-zag chains, coupled with the intercalation of tetrahedra, are determined by the overall stoichiometry. The chains could be combinations of four-octahedron-long, three-octahedron-long and two-octahedron-long segments, as represented in the leucophoenicite-humite merotypic series (Makovicky 1995). The common crystal-chemical feature of this family is the 1:2 ratio between the number of octahedrally coordinated cations and the number of anions. If the chemical formula is written as $O_{\mathrm{a}} T_{\mathrm{b}} X_{\mathrm{c}}$, where $O, T$ and $X$ represent the octahedrally coordinated cations, tetrahedrally coordinated cations and anions, respectively, the average number of octahedra in the segments of chains of octahedra can be expressed as $\mathrm{N}=\mathrm{a} / \mathrm{b}+1$. The true isotypes of $(\mathrm{Be}, \square)(\mathrm{V}, \mathrm{Ti})_{3} \mathrm{O}_{6}$, with four-octahedron-long chain segments (Table 6), are characterized by very similar sizes of octahedra, whereas the ratio between the radius of octahedrally and tetrahedrally coordinated cations exhibits a large variation, suggesting that it is primarily the relation of the valences that determines the composition of this structure type, and not the relation of atom radii of tetrahedrally and octahedrally coordinated cations.

Rewriting the formula as $(\mathrm{V}, \mathrm{Cr})_{2} \mathrm{BeO}_{4} \bullet \mathrm{TiO}_{2}$, and considering the structural similarities to norbergite, one could expect that with larger $(\mathrm{V}, \mathrm{Cr})$ :Ti proportions, a

TABLE 6. SIZES OF COORDINATION POLYHEDRA $\left(\AA^{3}\right)$ IN $(\mathrm{Be}, \square)\left(\mathrm{V}, \mathrm{Ti}_{3}\right)_{6}$ AND ISOTYPIC COMPOUNDS, PLUS TIVANITE

\begin{tabular}{|c|c|c|c|c|c|c|c|}
\hline & $\begin{array}{c}(\mathrm{V}, \mathrm{Ti})_{3}(\mathrm{Be}, \square) \mathrm{O}_{6} \\
1\end{array}$ & $\begin{array}{c}\mathrm{TiVO}_{3}(\mathrm{OH}) \\
2\end{array}$ & $\begin{array}{c}\mathrm{Mg}_{3} \mathrm{SiO}_{4} \mathrm{~F}_{2} \\
3\end{array}$ & $\begin{array}{c}\mathrm{Mn}_{3} \mathrm{SiO}_{4} \mathrm{~F}_{2} \\
4\end{array}$ & $\begin{array}{c}\mathrm{Fe}_{3} \mathrm{BO}_{6} \\
5\end{array}$ & $\begin{array}{c}\mathrm{Cr}_{3} \mathrm{BO}_{6} \\
6\end{array}$ & $\begin{array}{c}\mathrm{NbNi}_{2} \mathrm{BO}_{6} \\
7\end{array}$ \\
\hline $\begin{array}{l}\text { octahedral } \\
\text { cation(s) }\end{array}$ & $(\mathrm{V}, \mathrm{Ti}, \mathrm{Cr})$ & $(\mathrm{V}, \mathrm{Ti})$ & $\mathrm{Mg}$ & $\mathrm{Mn}$ & $\mathrm{Fe}$ & $\mathrm{Cr}$ & $\mathrm{Nb}, \mathrm{Ni}$ \\
\hline $\mathrm{V}_{\mathrm{ocl}} \quad \mathrm{V} 1$ & $10.62(1)$ & $10.7(5)$ & $12.03(3)$ & $13.63(3)$ & $10.97(2)$ & $10.22(6)$ & $10.45(4)$ \\
\hline $\mathrm{V} 2$ & $10.39(1)$ & $10.5(4)$ & $11.52(2)$ & $13.17(3)$ & $10.64(2)$ & $10.10(5)$ & $11.27(3)$ \\
\hline $\mathrm{V} 1 / \mathrm{V} 2_{\mathrm{oct}}$ & 1.02 & 1.02 & 1.04 & 1.03 & 1.03 & 1.01 & 0.93 \\
\hline $\begin{array}{l}\text { tetrahedral } \\
\text { cation }\end{array}$ & $\mathrm{Be}$ & - & $\mathrm{Si}$ & $\mathrm{Si}$ & B & B & B \\
\hline$V_{\text {tet }}$ & $2.36(1)$ & - & $2.193(7)$ & $2.196(8)$ & $1.68(1)$ & $1.78(4)$ & $1.68(2)$ \\
\hline anion(s) & $\mathrm{O}$ & $\mathrm{O}, \mathrm{OH}$ & $\mathrm{O}, \mathrm{F}$ & $\mathrm{O}, \mathrm{F}$ & $\mathrm{O}$ & $\mathrm{O}$ & $\mathrm{O}$ \\
\hline $\mathrm{V}_{\mathrm{occ}} \mathrm{N}_{\mathrm{tet}}$ & $4.50,4.40$ & - & $5.49,5.25$ & $6.21,6.00$ & $6.53,6.33$ & $5.74,5.67$ & $6.22,6.71$ \\
\hline
\end{tabular}

1 this work, 2 Grey \& Nickel (1981) (tivanite), 3 Gibbs \& Ribbe (1969) (norbergite), 4 Zenser et al. (2000), 5 Diehl \& Brandt (1975), 6 Rowsell \& Nazar (2001), 7 Ansell et al. (1982). 
series of structures of the type $\mathrm{nV}_{2} \mathrm{BeO}_{4} \bullet \mathrm{TiO}_{2}$ can exist, equivalent to those of the norbergite-clinohumite series $\left[\mathrm{nMg}_{2} \mathrm{SiO}_{4} \bullet \mathrm{Mg}(\mathrm{F}, \mathrm{OH})_{2}\right]$. Owing to a similarity in the sizes of coordination polyhedra of $\mathrm{V}, \mathrm{Nb}, \mathrm{Ti}, \mathrm{Fe}^{3+}, \mathrm{Ni}$, $\mathrm{Mg}$ and $\mathrm{Mn}^{2+}$ on one side, and those of $\mathrm{Si}$ and $\mathrm{Be}$ on the other, one could also expect solid solutions across the two series. However, because of difference in valences, more extensive solid-solutions would be conditioned by coupled substitutions involving both octahedral and tetrahedral sites, or substitution of $\mathrm{F}$ and $\mathrm{OH}$ for $\mathrm{O}$ at anion sites.

In the case of the Byrud mineral, a more interesting question is the structural consequence of a surplus of Ti over the ideal $1: 2 M^{4+}: M^{3+}$ ratio. A close relation to the structure of tivanite $\left(\mathrm{TiVO}_{3} \mathrm{OH}\right.$, Grey \& Nickel 1981) can give us some clues. As can be seen in Figure $3 \mathrm{e}$, the crystal structure of tivanite is directly related to the structural family previously described. The chains of octahedra are formed by an alternation of segments two and four octahedra long, but there are no tetrahedrally coordinated cations. One of the oxygen sites (the one shared by three octahedra from the same chain) is occupied by the $\mathrm{OH}$ group. Although $\mathrm{Ti}$ and $\mathrm{V}$ are described as being ordered between the two independent octahedral sites in the original description of the structure, there is no proof for this claim, because the situation as regards the coordination sizes is very similar to that in $(\mathrm{Be}, \square)(\mathrm{V}, \mathrm{Ti})_{3} \mathrm{O}_{6}$ (Table 6). We can infer that $\mathrm{Ti}$ and $\mathrm{V}$ are most probably disordered. One can suppose that kyzylkumite can easily form intergrowths on a very fine scale with tivanite-like or even rutile-like structural domains, and that this can explain the deviation from the ideal stoichiometry. The results of the crystal-structure analysis, which suggest vacancies at Be sites and a slight occupancy of the "empty" octahedral voids in the structure, which can be a consequence of the displacement of chains of octahedra because of "tivanite defects" in the structure, can also be explained by this assumption.

Substitution of $\mathrm{Ti}^{4+}$ for $\mathrm{V}^{3+}$ at octahedrally coordinated sites is supposed to introduce vacancies at Be sites, as discussed under Chemical Data. One can assume a solid solution extending from $\mathrm{BeV}_{2} \mathrm{TiO}_{6}$ to a hypothetical $\mathrm{Ti}_{3} \mathrm{O}_{6}$ with the same basic structure-type. However, the general structural features can hardly be retained without the stabilizing effect of a substantial amount of tetrahedrally coordinated cations.

Twinning in $(\mathrm{Be}, \square)(\mathrm{V}, \mathrm{Ti})_{3} \mathrm{O}_{6}$ (and other isostructural compounds, like norbergite) is due to a pseudotrigonal arrangement of the tetrahedron and the nine octahedra that share vertices with it (Fig. 4). Only one of the three symmetry planes, which would be present in an idealized group of this kind, is at the same time the mirror plane of the crystal structure, whereas any one of the other two can become the twin plane. As the two choices are fully equivalent, there is a possibility to form triple, and possibly cyclical twins (Fig. 5).
Figure 6 shows a projection of the reciprocal lattice of a twin in $(\mathrm{Be}, \square)(\mathrm{V}, \mathrm{Ti})_{3} \mathrm{O}_{6}$. It can be seen that twinning in this mineral (regardless if it is a double or triple twin) simulates a superlattice with periods $2 a, 4 b, c$, which gives $19.964,34.008$, and $4.548 \AA$, very close to the parameters found by Smyslova et al. (1981) for type kyzylkumite.

\section{Conclusions}

Our first recognition of the probable identity of the Byrud mineral and kyzylkumite was based on the strong similarities between their X-ray powder-diffraction diagrams (Table 2) and also on the fact that they are oxides of the same major elements $\mathrm{Ti}$ and $\mathrm{V}$, plus minor $\mathrm{Cr}$ and $\mathrm{Fe}$. The very large unit-cell proposed for kyzylkumite $\left(V=3088 \AA^{3}\right)$ and the $Z$ value, 18 , are suspicious. These features can be explained by twinning, and kyzylkumite is described as showing twinning striations parallel to the elongation, just like the Byrud mineral. The $b$ parameter of kyzylkumite and the $c$ parameter of the Byrud mineral are very close $(4.578$ and $4.551 \AA$, respectively) and the ratio between the cell volumes of kyzylkumite and the Byrud mineral ( $V$ $=386.8 \AA^{3}$ ) is almost exactly 8 . Our projection of an $l$ level from the reciprocal lattice of a twinned crystal shows that it can be interpreted as a single-crystal rectangular lattice with the other two periods of 19.964 and $34.008 \AA$, which correspond very well with the $c$ and $a$ parameters, respectively, proposed for the original kyzylkumite (directed along the present $a$ and $b$ axes, respectively).

We believe that the analytical data and the crystallographic data published for kyzylkumite cannot both have been obtained on the same pure mineral. On the basis of the X-ray-diffraction data, there is strong evidence that a mineral identical to the one found at Byrud was present also in the material described as kyzylkumite. The crystal-structure data show Be to be an essential part of the structure, together with $\mathrm{V}$ and Ti. Results of the crystal-structure analysis explain the departures from the ideal formula $\mathrm{BeTiV}_{2} \mathrm{O}_{6}$. The observed vacancies at the Be site can explain in part a surplus of the tetravalent element (Ti), observed in all datasets. Moreover, owing to close structural relations to tivanite and rutile, it would not be surprising if submicroscopic intergrowths in the form of tivanite or rutile modules are present, which is probably the case in the material from Byrud. It seems clear that $(\mathrm{Be}, \square)(\mathrm{V}, \mathrm{Ti})_{3} \mathrm{O}_{6}$ may form intimate intergrowths with larger masses of these two minerals, which on the whole will show large discrepancies in chemical compositions with respect to the ideal composition. This can be supposed to be the case in the original work on kyzylkumite. We believe therefore that a revision of kyzylkumite is necessary. 

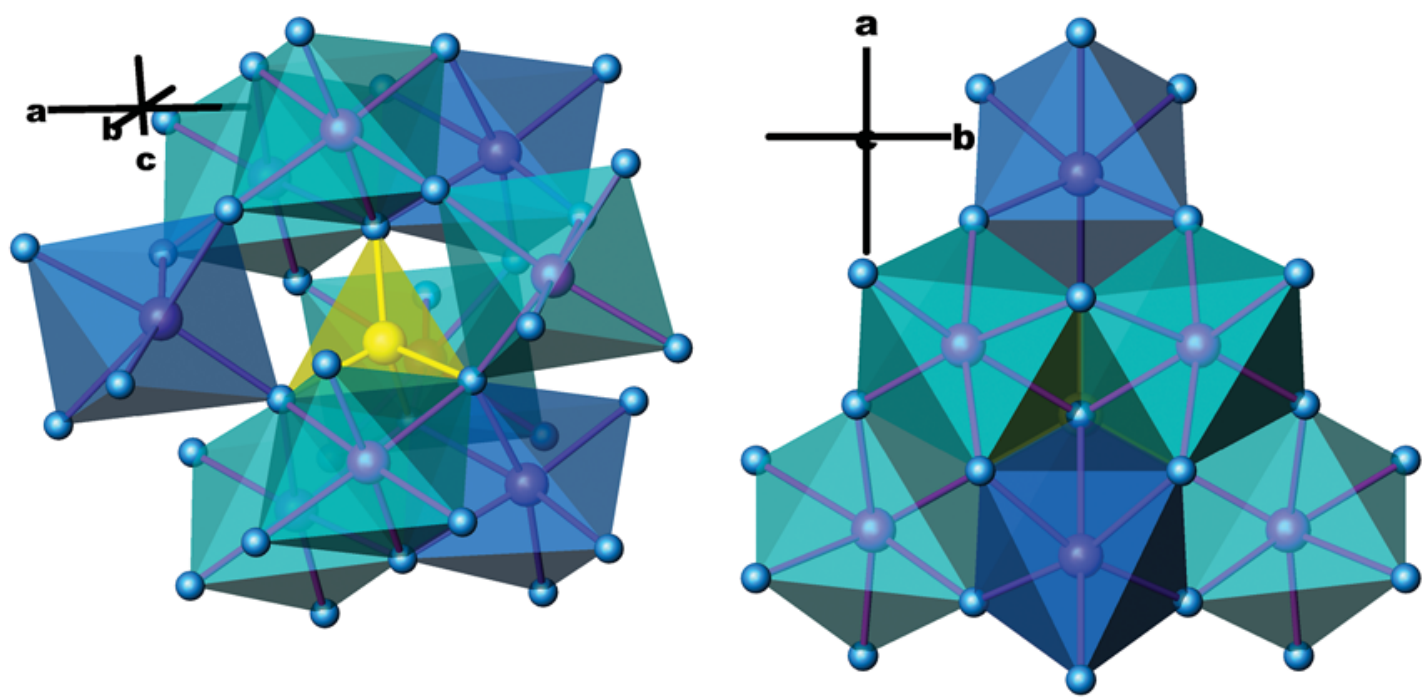

FIG. 4. Two views of the tetrahedral group and the nine surrounding octahedral groups in the structure of $(\mathrm{Be}, \square)(\mathrm{V}, \mathrm{Ti})_{3} \mathrm{O}_{6}$. Coloring as in Figure 2.

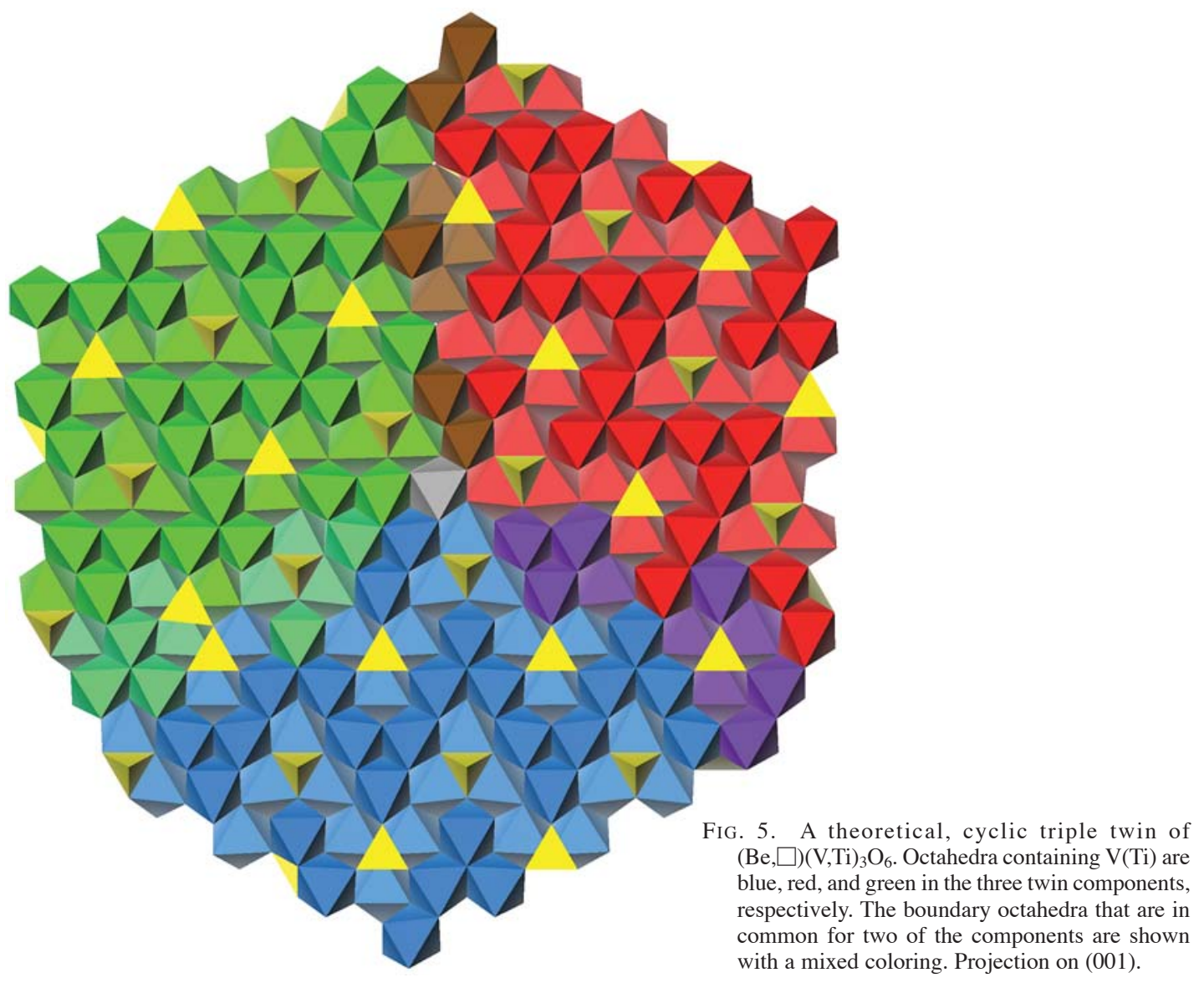




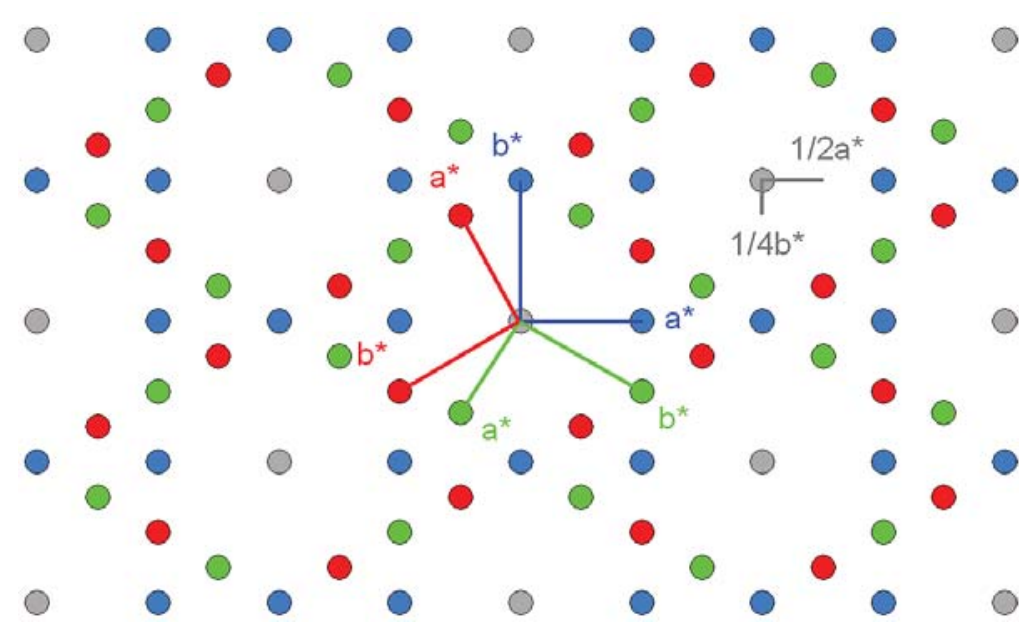

FIG. 6. Projection of the reciprocal lattices of a hypothetical triple twin of $(\mathrm{Be}, \square)(\mathrm{V}, \mathrm{Ti})_{3} \mathrm{O}_{6}$. The same coloring for the twin components as in Figure 5 is used. A twinned crystal simulates a lattice with 8( larger (crystal-)unit cell, the reciprocal periods of which are shown in addition. The relation between the lattice periods previously reported for kyzylkumite $\left(a_{o}, b_{o}, c_{o}\right)$ and those found in the present work for the Byrud mineral $\left(a_{n}\right.$, $\left.b_{n}, c_{n}\right)$ is: $a_{o}=4 b_{n}, b_{o}=c_{n}, c_{o}=2 a_{n}$

\section{ACKNOWLEDGEMENTS}

We thank the following for their kind assistance: $\mathrm{M}$. Erambert for help with the EMP analyses, L. Ottolini for providing information on Be and Li by SIMS, and M.N. Murashko for the loan of samples from the Koscheka deposit. Helpful comments from members of the Commission on New Minerals and Mineral Names are appreciated. Thoughtful comments from referees J.D. Grice and S.V. Krivovichev, as well as from Associate Editor E.S. Grew and R.F. Martin, have improved the presentation of the paper. The diffractometer used for the crystal-structure analysis was provided as a grant from the Danish National Research Council.

\section{REFERENCES}

Ansell, G.B., LeOnowicz, M.E., Modrick, M.A., Wanklyn, B.M. \& WONDRE, F.R. (1982): The structure of dinickel niobium(V) boron oxide $\mathrm{Ni}_{2} \mathrm{NbBO}_{6}$. Acta Crystallogr. B38, 892-893.

Balić-Žunić, T. \& Makovicky, E. (1996): Determination of the centroid or "the best centre" of a coordination polyhedron. Acta Crystallogr. B52, 78-81.

BALIĆ-ŽUnić, T. \& RAADE, G. (2003): The crystal structure of kyzylkumite, $\mathrm{BeV}_{2} \mathrm{TiO}_{6}$. 21st Eur. Crystallographic Meeting (Durban, South Africa), 145 (abstr.).
BALIĆ-ŽUnIĆ, T. \& VICKOVIĆ, I. (1996): IVTON: a program for the calculation of geometrical aspects of crystal structures and some crystal chemical applications. J. Appl. Crystallogr. 29, 305-306.

BRUKER AXS (1998): SMART, Version 5.054. Bruker Analytical X-Ray Systems, Madison, Wisconsin, USA.

BRUKer AXS (1999): Gemini, Twinning Solution Program Suite, Version 1.0. Bruker Analytical X-Ray Systems, Madison, Wisconsin, USA

BRUKER AXS (2003a): SAINT+, Version 6.45. Bruker Analytical X-Ray Systems, Madison, Wisconsin, USA.

BRUKer AXS (2003b): Twinabs. Bruker Analytical X-Ray Systems, Madison, Wisconsin, USA.

DieHL, R. \& BRANDT, G. (1975): Refinement of the crystal structure of $\mathrm{Fe}_{3} \mathrm{BO}_{6}$. Acta Crystallogr. B31, 1662-1665.

GibBs, G.V. \& RibBe, P.H. (1969): The crystal structures of the humite minerals. I. Norbergite. Am. Mineral. 54, 376-390.

GREY, I.E. \& NICKEL, E.H. (1981): Tivanite, a new oxyhydroxide mineral from Western Australia, and its structural relationship to rutile and diaspore. Am. Mineral. 66, 866-871.

HAZEN, R.M. \& Finger, L.W. (1986): High-pressure and hightemperature crystal chemistry of beryllium oxide. J. Appl. Phys. 59, 3728-3733. 
MAкоVicKY E. (1995): Structural parallels between the highpressure B phases and the leucophoenicite series. Am. Mineral. 80, 676-679.

Makovicky, E. \& Balić-Žunić, T. (1998): New measure of distortion for coordination polyhedra. Acta Crystallogr. B54, 766-773.

Peкоv, I.V. (1998): Minerals First Discovered on the Territory of the Former Soviet Union. Ocean Pictures Ltd., Moscow, Russia.

Rastsvetaeva, R.K., Evsyunin, V.G. \& Kashaev, A.A. (1995): Crystal structure of a new natural K,Na,Catitanoberyllosilicate. Kristallografiya 40, 253-257.

Reid, A.F., SABINe, T.M. \& WheELER, D.A. (1972): Neutron diffraction and other studies of magnetic ordering in phases based on $\mathrm{Cr}_{2} \mathrm{O}_{3}, \mathrm{~V}_{2} \mathrm{O}_{3}$ and $\mathrm{Ti}_{2} \mathrm{O}_{3}$. J. Solid State Chem. 4, 400-409.

RicE, C.E. \& RoBinson, W.R. (1977): Structural changes in the solid solution $\left(\mathrm{Ti}_{1-\mathrm{x}} \mathrm{V}_{\mathrm{x}}\right)_{2} \mathrm{O}_{3}$ as $\mathrm{x}$ varies from zero to one. $J$. Solid State Chem. 21, 145-154.

RowSELL, J.L.C. \& NAZAR, L.F. (2001): Synthesis, structure, and solid-state electrochemical properties of $\mathrm{Cr}_{3} \mathrm{BO}_{6}$ : a new chromium(III) borate with the norbergite structure. $J$. Mater. Chem. 11, 3228-3233.

Sacerdoti, M., Parodi, G.C., Mottana, A., Maras, A. \& Della VentuRA, G. (1993): Asbecasite: crystal structure refinement and crystal chemistry. Mineral Mag. 57, 315322.
SCHWARZ, D. (1991): Die chemischen Eigenschaften der Smaragde. II. Australien und Norwegen. Z. Deutsch. Gemmol. Gesellsch. 40, 39-66.

Sheldrick, G. M. (1997a): ShelXs97. Program for the Solution of Crystal Structures. University of Göttingen, Göttingen, Germany.

SHELDRICK, G.M. (1997b): SHELXL97. Program for the Refinement of Crystal Structures. University of Göttingen, Göttingen, Germany.

Smyslova, I.G., Komkov, A.I., Pavshukov, V.V. \& KuZnetsova, N.V. (1981): Kyzylkumite, $\mathrm{V}_{2} \mathrm{Ti}_{3} \mathrm{O}_{9}$, a new mineral of vanadium and titanium of a group of complex oxides. Zap. Vses. Mineral. Obshchest. 110, 607-612 (in Russ.). [Abstracted with this title in Am. Mineral. 67, 1982, 855-856.] English translation 1981 in International Geology Review 24, 740-744: Kyzylkumite, $\mathrm{V}_{2} \mathrm{Ti}_{3} \mathrm{O}_{9}$, a new complex oxide of vanadium and titanium.

SugiYAma, K. \& TAKeUChI, Y. (1991): The crystal structure of rutile as a function of temperature up to $1600^{\circ} \mathrm{C}$. Z. Kristal$\log r$. 194, 305- 313.

Zenser, L.-P., Gruehn, R. \& Weil, M. (2000): Synthese, Charakterisierung und Struktur von $\mathrm{Mn}_{3} \mathrm{SiO}_{4} \mathrm{~F}_{2}$. Z. Anorg. Allg. Chem. 626, 871-877.

Received August 9, 2005, revised manuscript accepted August 29, 2006. 